\title{
Nordic
}

\section{Studies IN Education}

Article | Peer-reviewed | Vol. 41, No. 4, 2021, pp. 279-294

\section{Hvordan vil du være pædagog? Et fagpersonligt dannelsesspørgsmål, som kalder på kvalificere( $n$ ) de faglige fællesskaber}

Line Togsverd

UC SYD, Sydjylland, Danmark

Jan Jaap Rothuizen

VIA University College Århus, Danmark

Contact corresponding author: jjr@via.dk

\begin{abstract}
In our research concerning the education of Danish pedagogues we found a common understanding that professionalism and personal involvement are not mutually exclusive, so we grapple with the relationship between them. We settle the problem with a reminder of the nature of education and upbringing as a cultural project based on values such as participation and emancipation: values that always have to be realized in unique situations. We argue that professionalism and personal involvement go hand in hand if they are embedded in communities of investigative practice, in which multiple forms of knowledge are brought into play.
\end{abstract}

Keywords: professionalism, situated knowledge, educational values, communities of investigative practice

\section{Introduktion: En studerende møder sig selv}

Lina, som er studerende på pædagoguddannelsen, fortæller i forbindelse med et gruppeinterview om en situation, hun har lært meget af i sin uddannelse. Det var i den første praktik, hvor vejlederen fik hende til at filme sig selv - en oplevelse, som gjorde fagligt og personligt indtryk. Hun fortæller:

Manuscript received: 29.09.2020. Manuscript accepted: 19.05.2021.

(C) 2021 L. Togsverd \& J. J. Rothuizen. This is an Open Access article distributed under the terms of the Creative Commons CC-BY 4.0 License. ISSN 1891-5949, https://noredstudies.org

Citation: Togsverd, L. \& Rothuizen, J. J. (2021). Hvordan vil du være pædagog? Et fagpersonligt dannelsesspørgsmål, som kalder på kvalificere(n)de faglige fællesskaber. Nordic Studies in Education, 41(4), 279-294. https://doi.org/10.23865/nse.v41.2685 
"og jeg var da lorte ... pædagog og jeg, jeg lagde ikke mærke til mig selv og det der med at lægge mærke til sig selv, og hvordan er jeg i situationerne [...] Det tror jeg bare, det gjorde meget for mig i forhold til, hvor ligger mit fokus. Ligger det på: "I skal sidde og lytte, når vi læser denne her bog" eller ligger fokus på, at det er ud fra deres perspektiv, at vi læser den her bog. Og der ændrede det rigtig meget for mig som pædagog, det her filmen, at jeg så på mig selv, og hvad det er for en pædagog, jeg gerne vil være [...] Og det var mit mål, at "I skal være lyttende, fordi nu har vi stilletime." Men det, der skete, det var, at den ene fik en bog i hovedet, og den anden væltede, og en tredje græd, og .. fordi de kunne jo ikke være stille. Så må man jo lave om på praksis, så var det pludselig ikke målet mere, der var vigtigt, men processen, der var vigtig. Og så kunne jeg bare mærke, hvordan jeg gerne ville være, fordi jeg var sådan en, jeg ikke ville være. Jeg kunne bare mærke, at det var faktisk ret ubehageligt. Altså jeg sad der og kom til at hive en i benet fordi, og jeg turde nærmest ikke filme mig selv, og jeg var ved at sætte den på pause mange gange, fordi jeg tænkte, at jeg skal ikke se mig selv i sådan en situation. Men det gav mig bare rigtig rigtig meget $i$ forhold til, hvem jeg er, og hvem jeg egentlig gerne vil være"

Signe [en medstuderende nikker engageret]: "Jeg tror, du har fat i noget i, at der, hvor man virkelig rykker, det er i sådan nogle situationer, hvor man tænker shit, det her, det fungerer slet ikke. Jeg var der, hvor jeg ikke vil være, jeg var den, jeg ikke vil være" (interview med studerende, vores fremhævninger)

Linas fortælling ovenfor handler på én gang om fagudøvelse og om hendes person. Hun ser sig selv i en pædagogisk praktisk kontekst og konfronteres med, hvordan hun forvalter sit pædagogiske ansvar. Og gennem mødet med sine egne handlinger og måder at være pædagog, kommer hun til en ny forståelse af, hvordan hun i grunden $\emptyset$ nsker at udøve sin praksis.

Fortællingen stammer fra én af to undersøgelser af pædagoguddannelsen, hvor vi bl.a. har interviewet pædagogstuderende, praktikvejledere, undervisere og ledere af pædagoguddannelsen for at finde ud af, hvad der kan antages at have betydning for, hvordan de studerende udvikler en professionsidentitet (Rothuizen et al., 2019; Togsverd \& Rothuizen, 2020). I de mange samtaler med uddannelsens aktører er det en gennemgående tematisering, at pædagoguddannelsen må handle om at støtte de studerende i at finde ud af, hvordan de vil være pædagoger.

Relationen mellem fag og person er et kendt, men også omdiskuteret tema i pædagogikken (Bayer, 2017). Spørgsmålet "Hvordan vil du være pædagog?" kan forstås som et spørgsmål, der lægger op til ren relativisme og subjektivisme. Altså som et spørgsmål, som ikke har meget med profession og faglighed at gøre, fordi det inviterer til, at professionsudøverens autoritet og begrundelser alene hentes i udøverens person. Polarisering sker, når man opstiller to muligheder: Enten er subjektivitet den vidensbaserede fagligheds modsætning, eller også anses anonyme metoder som gift for det relationelle pædagogiske arbejde, som pædagogen nødvendigvis må investere 
sig selv i. I denne artikel vil vi vise, at viden og subjektivitet ikke udelukker hinanden, men også, at faget bliver uomgængeligt, når det handler om at skulle at kvalificere svaret på spørgsmålet "Hvordan vil du være pædagog?". At være eller at blive pædagog forpligter på en pædagogisk faglighed, og svaret på spørgsmålet kan derfor hverken besvares individuelt eller relativt, selvom det skal besvares personligt og situationelt. "Hvordan vil du være pædagog?" og "Hvordan vil vi være pædagoger?" må løbende overvejes og undersøges intersubjektivt - i forpligtende faglige fællesskaber.

Relationen mellem viden og subjektivitet tematiseres i reglen med afsæt i professionsteori og i kundskabsteori, og selvom vi undervejs også trækker på disse discipliner ( $\mathrm{fx}$ gennem en reception af Aristoteles, 1998; Gilje, 2017; Grimen, 2008; Polanyi, 1962 samt Schön, 2001), går vi her ikke ind i en diskussion af og med dem. Artiklens ambition er at unders $\emptyset$ ge og udlægge relationen mellem viden, praksis og subjektivitet med afsæt i den åndsvidenskabelige pædagogik og handlingsvidenskabelige tradition (Biesta, 2018; Rothuizen, 2019 samt Saeverot, 2017). Det betyder, at vi tager udgangspunkt i en forståelse af pædagogik som en menneskelig praksis, der rummer egne spørgsmål, begrundelser og svar. I artiklen redegør vi for en unders $\emptyset$ gelse af relationerne mellem viden og subjektivitet med udgangspunkt $i$ en forståelse af pæedagogikkens egenart. Denne egenart udfoldes i artiklen som et projekt, der - gennem uddannelse, opdragelse og dannelsespraksisser - sigter efter at realisere og balancere de kulturelle værdier emancipation og participation. Vi forstår således pædagogik som et kulturelt projekt, som opererer gennem handling, begrebsliggørelse, fagsprog og handlingsvidenskabelig forskning. Det er et udgangspunkt og et perspektiv, der i sig selv rummer en stillingtagen i debatten om, hvilken slags videnskab pædagogik er, og om, hvilke videnskab(er) der udforsker det pædagogiske domæne (Bellmann, 2017; Biesta, 2013, 2015a samt Oettingen, 2018). Det er også en tilgang, som har til hensigt at genopdage og videreudvikle en pæedagogisk begrebsligg ørelse af uddannelsesmæssige processer, handlinger og mål - og kritiske overvejelser og undersøgelser heraf - herunder en pædagogisk begrebsliggørelse af de centrale, men også komplekse relationer mellem viden og faglighed, praksis og subjektivitet, som er denne artikels centrale problematik.

Artiklen består som nævnt indledningsvist af to dele. Først en systematisk behandling af spørgsmålet om forholdet mellem fag (pædagogik) og person og dernæst en unders $\emptyset$ gelse af forholdet mellem viden og udvikling af faglighed i relation til pædagogisk professionsudøvelse. Artiklen afsluttes med en opfordring til, at vi må interessere os for og kvalificere det fællesskab, hvori pædagogisk faglighed undersøges, bringes i spil og kultiveres.

\section{Artiklen er forskningsbaseret - hvad vil det sige?}

Vi har gennem årene været optagede af at besvare spørgsmålet om, hvordan pædagoger uddannes. I første omgang som undervisere i uddannelsen, senere, fra 2011 af, har vi i flere forskningsprojekter unders $\emptyset$ gt forskellige aspekter af uddannelsen (Rothuizen, 2015; Rothuizen et al., 2013, 2019 samt Togsverd \& Rothuizen, 2020). 
Spørgsmålet om, hvordan pædagoger uddannes, må adresseres empirisk og normativt. Spørgsmålet om, hvordan pædagoger bør uddannes, er allerede til stede, når man stiller og besvarer spørgsmålet om, hvordan de uddannes. Diskuterer man pædagogik, er denne diskussion indlejret i eftersøgningen af god pædagogik. Derfor er pæedagogisk forskning hverken en neutral eller objektiv registrering af virkeligheden, endsige blot en normativ spekulation over, hvordan den bør være, men en kombination af feltarbejde, begrebsudvikling og teoridannelse.

Også i denne artikel beskæftiger vi os med den kombination, hvor en første begrebssætning har betydning for feltarbejdet, og hvor feltarbejdet giver anledning til en fortsat begrebsudvikling. Det er en hermeneutisk tilgang, hvor vi gennem feltundersøgelser og teoretiske analyser og indsigter bevæger os fra forforståelser til anderledes forståelser (Gadamer, 1999). Som tidligere nævnt kommer den teoretiske inspiration til analyserne i denne artikel af et mangeårigt arbejde med at forstå og kvalificere den tilgang, der karakteriserer pædagogikkens åndsvidenskabelige tradition (Jørgensen et al., 2019; Rothuizen, 2001, 2015, 2019 samt Rothuizen \& Togsverd, 2020). Det er en forskningspraksis, vi betegner som handlingsvidenskabelig, fordi den beskæftiger sig med menneskelige handlinger og sigter mod at tilvejebringe en viden, der kan udvide og kvalificere menneskers pædagogiske handlemuligheder. Vi må derfor begynde med at indkredse og udlægge vores forståelse af pædagogikken og dens egenart.

\section{Hvad er pædagogik?}

Det er indlysende, at spørgsmålet om, hvordan man vil være pædagog, hverken kan affejes eller besvares for let. Når man er pædagog, træder man ind i et fag; en profession med egne værdier og standarder, og man påtager sig at varetage en funktion eller opgave, om man vil, som vi som samfund værdsætter. Pædagogik er betegnelsen for en praksis og for en disciplin, der bygger på et fælles kulturelt grundlag. Pædagogikkens kulturelle grundlag må i forlængelse af den åndsvidenskabelige tradition ses som et værdibaseret projekt, som vi i anden sammenhæng (Rothuizen, 2015, 2019) har beskrevet som en del af det modernes projekt - udgangen af den selvforskyldte umyndighed, som Kant formulerede det (Kant, 1987). Overgangen fra det traditionelle til det moderne samfund gjorde pædagogikken til et projekt, man skulle formulere sig om og have ambitioner med (Mollenhauer, 1983; Rothuizen \& Togsverd, 2020). Hvor man før kunne nøjes med at socialisere børn ind i det bestående, skal borgere i det moderne frie og demokratiske samfund opdrages til både selvstændighed og til at kunne indgå som myndige væsener i dynamiske fællesskaber. Pædagogikken artikuleres i 1700-tallet som civilisationskritik, både hos Locke, Rousseau og Kant, og henter sine begrundelser i, at den nye generation skal kunne overskride og udvikle det bestående. Emancipation og participation bliver nøgleord i det pædagogiske projekt og er fortsat kerneværdier, som vi i dag genfinder i de formålsparagraffer, som i Serviceloven, Dagtilbudsloven og Folkeskoleloven rammesætter pædagogers professionsudøvelse. Allerede Locke, Rousseau, Kant og lidt senere Marx havde vidt forskellige forestillinger om, hvordan 
projektet skulle angribes, og den dag i dag er både projektet og faget fortsat kendetegnet ved en polyfoni, der bunder $i$, at der er indbygget en række antinomier i projektet og dermed også i faget (se fx Løvlie, 2007; Oettingen, 2006).

Pædagogikken opstår både som en praksis, hvori disse værdier søges realiseret, og som en videnskabelig disciplin, der rummer refleksioner over denne menneskelige praksis (Løvlie, 2003). Refleksionerne er nødvendige, for det særlige og besværlige ved det pædagogiske projekt er, at det er polyfont og modsætningsfuldt. Værdierne trækker i hver sin retning, samtidig med at de er hinandens forudsætninger. Barnet kan eksempelvis ikke udvikle selvstændighed uden at bevæge sig i dynamiske fællesskaber. Ligesom fællesskaber kun kan udvikles og eksistere, når de består af selvstændige individer, der kan tage ansvar for det. Opgaven er også paradoksal, fordi den går ud på at udvikle noget, som kun den anden selv kan være ophav til (Biesta, 2020; Løvlie, 2007 samt Steinsholt \& Løvlie, 2005). Dernæst er opgaven kompleks, da ethvert pædagogisk forl $\emptyset \mathrm{b}$ har betydning for, hvad der sker med den og de, der er involveret i forløbet, indenfor fire forskellige dimensioner: Det har betydning for deres socialisering, kvalificering, subjektificering og civilisering. Hvad skal vægtes hvornår, og hvad koster det at nedprioritere det ene frem for det andet? (Biesta, 2015b) ${ }^{1}$. Det komplekse, modsætningsfulde og paradoksale udgør pædagogikkens grundlagsproblematik, som implicerer, at pædagogikken som videnskabelig disciplin ikke kan producere sikker viden og lede praksis. Producerede den pædagogiske videnskab sikker viden om, hvad der virker, så ville den afvikle det pædagogiske projekt. Pædagogik har et principielt teknologisk underskud (Luhmann \& Schorr, 1979). For udøverne af pædagogik betyder det, at de må handle på et grundlag af ikke-sikker viden; de må undervejs træffe valg, og de kan ikke på forhånd vide, hvad der kommer ud af dem. Hverken vidensdisciplinen pædagogik eller pædagogisk praksis har sit objekt - den og dem, der skal opdrages - til rådighed (Løvlie, 2003). Derfor lykkes det heller ikke altid at komme i mål inden for alle fire dimensioner (Oettingen, 2019).

\section{Livshistoriske forudsætninger og værdier har betydning}

Når pædagogik er en værdibaseret praksis, der fordrer, at udøveren gennem sine handlinger træffer valg om, hvordan værdierne bedst realiseres og balanceres i konkrete situationer, så bliver udøveren et afgørende led. Skal der træffes valg på et usikkert

$1 \quad$ Nogle læsere vil genkende tre af begreberne fra Gert Biestas pædagogiske filosofi og måske undre sig over, hvorfor der her er føjet et fjerde begreb (civilisering) til. Det, vi her kalder civilisering, er ikke udeladt hos Biesta - det kan tænkes ind i både subjektificering og socialisering. Grunden til, at det her fremhæves, er vores kulturhistoriske og hermeneutiske tilgang, der tager afsæt i, at individ og fællesskab i moderniseringsprocessen uddifferentieres og dermed stiller det pædagogiske spørgsmål om hhv. emancipation og participation. Biesta derimod søger sit afsæt i en eksistentiel etik. Han kommer i фvrigt sammen med Osberg i 2021 også frem til en model, hvor pædagogik (education) står midt i en trekant, der er spændt ud mellem det symbolske felt (viden), individualitetens felt og det politiske felt (fællesskabet), og hvori det pædagogiske beskrives som emergerende (Osberg \& Biesta, 2021). 
grundlag, så pådrager man sig et personligt ansvar, for det er kun dén person, der tager ansvar i netop dén situation, der kan træffe netop dét valg. Derfor er det ikke ligegyldigt, hvilken pædagog der står i situationen.

I vores undersøgelse træder det frem, at de studerende på pædagoguddannelsen har det tilfælles, at de har et stærkt engagement og en stærk personlig drivkraft for at vælge faget. Anden forskning påpeger også, at både lærer- og pædagogstuderende og lærere og pædagoger i høj grad vælger deres uddannelse på baggrund af værdier og idealer, uanset alder, social baggrund og anciennitet (Bayer et al., 2012; Hansen et al., 2010; Harrits \& Olesen, 2012; Manuel \& Hughes, 2006; Olsen, 2015, 2013; Watt et al., 2012 samt Watt \& Richardson, 2007). Når de studerende fortæller om deres uddannelse, er det helt tydeligt, at der er sammenhæng mellem dét, at de har valgt uddannelsen; dét, de kommer fra; og den måde, de forstår sig selv.

Nogle studerende vælger uddannelsen, fordi de har et overskud, de gerne vil dele:

"Det er det der med at hjælpe folk, jeg brænder for, og ligesom at være et forbillede på en eller anden måde" og: " ... så det har jeg altid haft lyst til at give videre".

Andre fortæller, at de begynder, fordi de har oplevet, hvordan de selv eller en nærtstående er blevet svigtet. De vil gerne bidrage til færre svigt i fremtiden og fortæller om de børn eller unge, de gerne vil støtte:

"Jo, jeg ved lige præcis, hvad det handler om. Det handler om, hvad for et blik de har i фjnene."

Atter andre er motiveret af, at de har erfaret, at opdragelse og (social)pædagogisk arbejde er meningsfuldt, gør dem glad, og giver dem mulighed for at tage et ansvar:

"Det der med at, ja komme på arbejde og så kan man føle, når man går hjem, at man har gjort en forskel for måske et barn eller to børn eller bare den dag. Og så ja. Det synes jeg var en god følelse."

Erfaringerne og værdierne er mangeartede, men de studerende på pædagoguddannelsen er i meget høj grad drevet af deres livshistoriske erfaringer og værdier og en stærk moralsk orientering - et $\emptyset$ nske om at blive gode pædagoger (Bille et al., 2017 samt Mockler, 2011).

I pædagogisk praksis konkretiseres og balanceres værdier. Derfor er pædagogen som person i spil, og det er netop dét, der tiltaler de studerende. Men pædagogiske handlinger og valg - svaret på, hvordan man vil være pædagog - kan ikke være tilfældige eller udelukkende baseret på personlige og subjektive vaner og præferencer. Som pædagog er man bundet af de faglige værdier, som kendetegner det pædagogiske projekt, og som vi i denne artikel beskriver som emancipation og participation. Det betyder, at den studerendes personlige værdier og de faglige værdier skal kalibreres - i første omgang i uddannelsen. 
Lina, som fortæller ovenfor, er et godt eksempel på, hvordan den livshistorisk forankrede moralske og værdimæssige orientering bevæger sig i løbet af pædagoguddannelsen. Hun er oprindeligt uddannet fris $ø$ r, men oplevede ikke at kunne finde mening i arbejdet. Hun har altid kunnet lide børn og er igennem uddannelsen blevet optaget af børns rettigheder (participation) og perspektiver (emancipation), som hun synes, der bør være mere opmærksomhed på i praksis. Den optagethed, disse værdier eller dén moralske orientering, er derfor også et centralt tema i hendes fortælling om arbejdet med at finde frem til, hvordan hun vil være pædagog. Mange af de studerende, vi har interviewet, refererer til mødet med teori og viden om fx børneperspektiver, anerkendelse og inklusion som indsigter, der bevæger dem. Men helt gennemgående refererer de især til mødet med medstuderende, som har andre typer af erfaringer, andre forholdemåder og andre værdier, som noget der i sig selv er kvalificerende i deres uddannelse til pædagog. De fortæller, at de derigennem lærer sig noget om deres egne værdier og forståelser af, hvem de er, og hvordan de vil være pædagoger. Vi fortolker udsagnene som beretninger om, hvordan de studerende oplever at arbejde med en kalibrering af deres værdier og moralske orientering som en helt central dimension af deres uddannelse. Ikke fordi de skal blive ens, men fordi de bevæger sig ind i en dannelsesproces, hvor deres selv- og omverdensforhold kommer i spil. De møder både noget, de allerede kender, og som de måske kan identificere sig med, men de møder også noget, som er dem fremmed og anderledes, som de bliver berørt af, og som derved kan bidrage til deres fagpersonlige udvikling. De om-danner sig, sådan at de bliver til regulære fag-personer og udvikler deres forståelser af og perspektiver på, hvad det indebærer at konkretisere og udleve pædagogiske værdier.

Forholdet mellem fag og person er således et intimt forhold i pædagogikken. Fagliggørelsen af opgaven med at realisere de kulturelle værdier sker ikke på bekostning af det personlige engagement, men igennem dette engagement. Vel skal det personlige - de synsninger og handlingstilbøjeligheder, som man bærer med sig bringes under faglig kontrol, men ikke gennem professionel distance og objektivering, som de aktuelle professionsbachelorbekendtgørelser i Danmark ser ud til at foreskrive (Larsen, 2013). Hvordan kan man så forestille sig, at fagliggørelse foregår, når den ikke skal indtræffe som en udskiftning af nærhedens blik med afstandens blik (Alrø et al., 2020)? For Lina går vejen mod at blive pædagog ikke gennem distance til børnene, men netop gennem mere nærhed til børnene og gennem en omtanke for det, som har pædagogisk betydning. Situationen og oplevelsen af ikke at slå til bliver et incitament til fagpersonlig udvikling, til kalibrering af værdier, i retning af en opd(r)agelse af dét, der for hende bliver et nøglespørgsmål, nemlig: hvem jeg egentlig gerne vil være som fagudøver.

\section{Så må man jo lave om på praksis: situeret viden}

Vi fortolker Linas fortælling som en fortælling om at gå fra ét udgangspunkt, blive overmandet af, at der sker noget, som man ikke havde ventet og ikke kan styre, til så at finde et nyt sted at stå - en anden måde at være udøver på. Lina fortæller, at hun 
begynder seancen med et $\emptyset$ nske om en stilletime, med en tro på, at dét er værdifuldt. Hun gør et spontant fors $\emptyset \mathrm{g}$ på at realisere det værdifulde i en konkret situation og slipper ikke så godt fra det: "den ene fik en bog i hovedet og den anden vceltede og en tredje grced". Lina skyder ikke skylden på de umulige unger, men synes at have forstået, at det netop er pædagogens opgave at bidrage til, at også de kan realisere nye muligheder. Det er hende, der står med det pædagogiske ansvar. Derfor er det også Lina, der må lave om på sin praksis. Linas fortælling er en fortælling om at blive konfronteret med, at ens værdier ikke slår til eller simpelthen ikke kommer i spil. Hvad det skyldes, kan man have forskellige bud på: Måske viser børnene hende, at stilletimen ikke lige er sagen, måske kommer hendes egen kropsligt-sanselige tilstedeværelse til at signalere en uro, som blander sig med og forstærker børnenes uro, eller måske er der noget helt tredje i spil. Uanset kan dét, der sker for hende som praktikant, ske for selv den bedste; at dét, man med de bedste intentioner begynder med, falder helt til jorden. Med Biesta kan vi sige, at pædagogik er et svagt projekt, at der er risiko for, at det, man gerne vil realisere, ikke bliver til. Men pædagogik er ifølge Biesta også et forunderligt og vidunderligt projekt (Biesta, 2009, 2014), for når man får øje på den andens personlige udvikling, når man făr øje på, at der dannes et frit fællesskab, så er det en gave. Ligesom det formentlig vil være en gave for en praktikvejleder, når Lina oplever, at "det gav mig bare rigtig meget $i$ forhold til, (...) hvem jeg egentlig gerne vil vare".

Det, som Lina, og enhver anden pædagog, bringer i spil i konkrete situationer, er situeret viden. Ikke teknisk viden, en opskrift på, hvordan man kommer fra A til B, men en konkretisering af pæedagogikkens almene vardier i en specifik situation. Vi kender dem under forskellige betegnelser som selvstændighed, anerkendelse, deltagelse, inklusion og fællesskab, demokrati og ansvarlighed - emancipation og participation. Værdierne er ikke vanskelige at blive enige om, det svære er, at de altid først realiseres i konkrete og altid forskellige situationer og derfor også altid på forskellig vis. I den konkrete situation situeres viden, ofte i form af en spontan handling, altså en handling, der springer ud af det handlingsberedskab, man har. Det handlingsberedskab er selvfølgelig knyttet til, hvem man er, til de værdier, man finder det meningsfuldt at formidle, og til de situationer og relationer, man indgår i. Situeret viden er omdrejningspunktet i pædagogisk arbejde. Spørgsmålet er ikke, hvordan det kan undgås, for det kan det ikke. Spørgsmålet er, hvordan den situerede viden kan kvalificeres.

\section{Faglig kvalificering af situeret viden}

Situeret viden er ikke noget, nogen - heller ikke en profession - kan have monopol på. Men den situerede viden kan være mere eller mindre kvalificeret, mere eller mindre god og mere eller mindre hensigtsmæssig i et pædagogisk perspektiv. Faget forpligter. Den situerede viden skal gerne leve op til og udvikles på baggrund af nogle faglige kriterier. I det følgende uddyber vi forholdet mellem situeret viden og anden viden, og vi lægger vægt på, at pædagogen gennem sit vidensarbejde både er bruger af viden og producent af viden: Hun forbinder sig med faget. I et sidste afsnit reflekterer vi over det karakteristiske træk ved situeret viden, at det ikke er sikker viden. Det indebærer, 
at pædagogen løbende må spørge sig selv "Hvordan vil jeg være pædagog?" og også løbende må søge svar på netop det spørgsmål. Pædagogen må selv besvare spørgsmålet og løbe risikoen for, at hendes eller hans svar viser sig ikke at være gode, og at der på ny skal søges viden og svar. Netop fordi den situerede viden ikke er sikker viden, er det, både i al almindelighed og i professionel sammenhæng, ikke godt at stå alene med det. Ansvaret må deles, og man må både udsætte sig for andres viden og vidensøgning, og man må efterspørge deres hjælp. Det er derfor, det er afgørende, at der både på pædagoguddannelsen og i pædagogiske institutioner er et velfungerende fagligt milj $\emptyset$.

\section{Pædagogen er både bruger og producent af viden}

Det, vi har benævnt som situeret viden, er også kendt under andre betegnelser. Man taler eksempelvis om viden-i-handling, om dømmekraft, om praktisk viden, om phronesis, om pædagogisk takt, om retningsgivende viden, om etik og om indekseret viden. Det, der forener disse forskellige betegnelser for vidensformer, er, at generel, almengyldig viden skal omsættes til noget, der er konkret i en enestående situation. At en situation er enestående, betyder, at den kun findes i den ene version: på dette tidspunkt, med disse mennesker, i denne kontekst. Derfor kræver omsætningen af det abstrakte til det konkrete et valg; man gør det bedste, man kan i situationen, men der er ingen sikkerhed for, at det "virker" eller vil vise sig at være "god pædagogik". Situeret pædagogisk viden er hverken en ukritisk tilpasning til en eksisterende praksis eller en handlingsanvisning, som foreskrives af teori eller af statistisk signifikante korrelationer. Situeret viden ligger i mellemrummet mellem praksis og teori (Herbart, 1986; Løvlie, 2015; Manen, 2015; Oettingen et al., 2007 samt Rothuizen, 2021). Vi kender det fra hverdagslivet, dér, hvor man for eksempel gerne vil være en god ven eller leve efter bæredygtighedsprincipper. Vi ved, at det er vigtigt og godt at gå efter, og vi ved også, hvad det vil sige, når vi eksempelvis møder én, der er en god ven. Men hvad det konkret betyder i hver enkelt situation, ja, det må vi selv finde frem til, og vi risikerer at komme til kort, også ud fra egne kriterier. Ligesom Lina oplever det.

Vi bruger betegnelsen situeret viden i denne artikel, fordi vi vil tydeliggøre, at der er tale om viden, som står i en åben forbindelse med andre vidensformer. Det er en viden, som kan udvikles, og som er en del af den faglighed, man kan arbejde systematisk med at tilegne sig. Alt for ofte bliver det, som ikke er direkte udledt af forskning eller teoretisk viden, betegnet som synsninger, private vurderinger, mavefornemmelser, personlige holdninger og som "vidensformer, der indimellem fremstår som esoteriske (Horobin, 1983), mystiske (Ahlström, 1988 og Bayer, 2017) og som en slags Black Box, der vanskeligg $ø \mathrm{r}$ fx pædagogprofessionens vidensautoritet (Harrits, 2019) og en øget vidensbasering af pædagogisk praksis." (Bayer, 2019). En sådan problematisering af pædagogers vidensgrundlag og praksis bunder i den udbredte forståelse af, at viden enten er objektiv eller subjektiv, enten sikker eller privat og personlig. Vores mange interviews med pædagoguddannelsens aktører indikerer, at det er en dikotomi, som kan trænge til overskridelse. Selvom det unægtelig er sådan, at mennesker har synsninger, mavefornemmelser, personlige holdninger og fordomme, så betyder det 
ikke, at disse fænomener nødvendigvis lever et liv uden for vidensuniverset. Fænomenologen og pædagogen Max Van Manen har gennem sine studier af læreres viden i handling beskrevet denne sansende, fornemmende værdiorienterede og situationelle viden, som "knowing what to do when you don't know what to do" (Manen, 2015), hvorved også han betoner, at de orienteringer, pædagoger og lærere bringer i spil i konkrete situationer, og som har en stærk moralsk og værdimæssig pædagogisk orientering, netop må betragtes som viden.

I en pædagogisk professionel sammenhæng bør også den form for viden-oghandlinger være åben for kritik, ligesom både viden og handlinger må udvikles og kvalificeres i et samspil mellem mennesket, verden og tilgængelig viden i professionsfælleskabet. Resultatet bliver aldrig sikker viden i betydningen objektiv viden, men noget som Grimen og Gilje benævner som praktiske synteser (Gilje, 2017 og Grimen, 2008). I hermeneutikkens sprog kan det benævnes som en anderledes forståelse, der kommer til udtryk i både en anderledes forståelse af én selv og af verden (Gadamer, 1999). Pædagogisk faglighed implicerer således, i vores optik at pædagogen som en hverdagshermeneutiker arbejder aktivt med sine forståelser og sin situerede viden og dermed også făr andre handlemuligheder - som da Linas vejleder støtter hende, da hun får hende til at filme sig selv og overveje sine handlinger.

Linas fortælling er i vores fortolkning en fortælling om at blive opmærksom på, at hendes situerede viden ikke slår til, fordi "jeg var sådan en, jeg ikke ville være". Hverken hendes forforståelse af den pædagogiske hverdag eller af sig selv holdt stand, da hun gik i gang med sit stille-time-projekt, og ubehaget er til at forstå i fortællingen. Signe, en af Linas medstuderende, genkender tydeligvis erfaringen med, at der er noget, der ikke stemmer; der er en mislyd, og hendes kommentar tyder på, at hun også genkender den ny-orientering, som følger. Det skal undersøges, hvor mislyden kommer fra, og der skal et andet handlingsberedskab til.

Lina udvikler sin situerede viden ved at gå ind i en nærmere undersøgelse. "Hvad kan være vedkommende for disse børn?" kan vi formode, at hun har spurgt sig selv om. Måske overvejer hun også, om det mon er det samme for dem alle? Hun kan overveje, hvad der skal til for at gøre noget vedkommende for børnene, og hun kan overveje, hvorfor det er bedre, end at børnene bare skal lære at sidde og lytte, når hun læser? Hvornår mon de har mest overskud til at afprøve, om noget, der kræver en smule anstrengelse, måske er vedkommende? Hun kan som studerende unders $\emptyset$ ge, om man på stedet har erfaringer med det? Om der er andre, andre steder, der har erfaringer med det? Måske er det også relevant for hende at overveje og undersøge, om dét, der sker, er, at hun mister fodfæste, ikke lægger mærke til sig selv? Måske får hun mod på at få hjælp til at fastholde fokus på værdien: at børnene skal øve sig $\mathrm{i}$ at lytte.

Pointen med de mange spørgsmål ovenfor er at pege på, at Lina må søge viden, førend hun kan udvikle sin faglighed og producere anderledes situeret viden. Hun må undersøge, inden hun kan undergå en udvikling; forstå anderledes for at komme til at kunne handle anderledes. Hun skal også gerne vide, hvor og hvordan hun kan søge den viden, hun har brug for. Hun har brug for at vide noget om pædagogikkens 
grundværdier og grundlagsproblem og om, hvordan de har været fortolket over tid, såvel i teori som i praksis. Hun har brug for viden om børneperspektiver og om de konkrete børns livsvilkår og udvikling. Hun har også brug for viden om, hvordan andre på stedet gør eller har gjort for at få en rolig stund med en gruppe børn, ligesom hun har brug for den viden og de indsigter, der affødes ved at reflektere over sig selv som fagperson. Hun har brug for at overveje, hvad hun vil kæmpe for, hvorfor netop dét er så vigtigt for hende, men også, hvordan hun selv kan komme til at stå i vejen for det. Hun kan søge viden og indsigt i sådanne spørgsmål ét efter ét, alt efter hvornår de opleves som påtrængende og relevante for hende.

Pointen er, at pædagogen - i dette tilfælde Lina - løbende har brug for at kvalificere den situerede viden, og at hun på vejen dertil må søge forskellig slags viden, men altid med udgangspunkt i det konkrete. For at producere viden må hun undersøge. I sine unders $\emptyset$ gelser trækker hun på viden, som i forvejen er til stede, og for at producere viden må hun igen knytte den til hendes egen situation. Det er ikke nok at have en generel viden om børns udvikling, hvis ikke den kan knyttes til netop de børn, hun har med at gøre, og til de pædagogiske værdier, hun har fundet frem til er væsentlige. På den måde må hun pendulere mellem den viden, der i forvejen er til stede, og den pædagogiske situation, hun selv er en del af. Derved indgår hun i en selvopdragelsesproces, hvorigennem hun finder nye svar på, hvordan hun vil være pædagog.

\section{Spørgsmålet "Hvordan vil du være pædagog?" stilles og besvares i det faglige miljø}

$\mathrm{Nu}$ kan vi jo forestille os, at Lina reflekterer og søger viden og derved kommer til at ændre sin praksis, så hun i højere grad kan være den pædagog, hun kan stå inde for. Vil resultatet så automatisk være "god pædagogik", vil hendes faglighed være større og bedre? Måske, og måske ikke. For pædagogen er det sådan, at hun ikke kan reflektere sig til sikker viden, til det eneste rigtige at gøre, til det, som alle fagfolk ville komme frem til, hvis de skulle vurdere situationen, og hvordan den skulle håndteres fagligt. Man kan derfor argumentere for, at dét, som Lina tænker og gør efter sine refleksioner og sin vidensøgning, fortsat er noget, der kommer ud af en "black box", noget mystisk og subjektivistisk, som kun Lina har adgang til. Man kan derfor med god ret spørge, om vores søgning efter, hvordan situeret viden kan kvalificeres, trods gode hensigter ender i en relativistisk position, hvor det i sidste ende er pædagogens person, der bliver autoritet i forhold til skøn og vurderinger?

Sådan kan det godt se ud, og derfor må der tilføjes noget: Pædagogik er ikke kun et personlig projekt - Linas projekt - men også netop et fagligt og kulturelt projekt. Vi har i artiklen beskrevet det kulturelle projekt som kendetegnet ved to grundværdier, der på en og samme gang er hinandens forudsætning og trækker i hver sin retning: emancipation og participation. Ligesom vi har peget på, at pædagogik rummer den grundlagsproblematik, at pædagogik og opdragelse sigter mod noget, som kun barnet selv kan frembringe. Her gives ingen sikker viden eller entydige handlemuligheder, og derfor kommer man ikke udenom, at den, der er på i situationen, bærer 
et ansvar for, hvordan den udvikler sig. Personen kan man ikke komme udenom. I en faglig sammenhæng må den situerede viden kunne tåle at blive genstand for en faglig unders $\emptyset$ gelse, hvori man trækker på forskellige typer viden. Netop fordi der er mange videnskilder, og fordi der ikke er en genvej til sikker viden, kan man ikke nøjes med det, man selv finder. Der må åbnes op for polyfonien, når spørgsmålet "Hvordan vil jeg være pædagog?" skal besvares.

Den situerede viden og spørgsmålet "Hvordan vil jeg være pædagog?" står både til diskussion i en offentlighed, der har en interesse i det kulturelle pædagogiske projekt, og i en faglig offentlighed, hvor deltagerne har en fælles interesse $i$ at forvalte en institutionaliseret, social praksis. Hertil kommer, at deltagerne i den faglige offentlighed har adgang til og kan st $\emptyset t$ te hinanden i at s $\emptyset$ ge relevante former for viden, der kan underst $\emptyset$ tte en praksis, som balancerer fagets værdier. Dette perspektiv på professionsudvikling og på professionelt ansvar underbygges af den idealtypiske professionsmodel, hvor professionen udøver noget, som har samfundsmæssig værdi, men hvor den faglige autonomi og kontrol først og fremmest forstås og reguleres kollektivt: "Det er professionen forstået som kollegiet af fagfæller, der sammen har autonomi og kontrol over egen profession og arbejde, herunder kompetencerne til at bedømme den faglige såvel som moralske kvalitet af dette arbejde." (Harrits, 2019). Derfor må situeret faglighed, svaret på spørgsmålet "Hvordan vil jeg være pædagog?", udvikles i et fagligt forum, et fagligt miljø, hvor man er sammen om at identificere udfordrende, vanskelige og løfterige pædagogiske situationer, og hvor den fælles ledetråd er den fælles faglige og moralske orientering: interessen for at udøve god pædagogik. Det er det faglige fællesskabs intersubjektivitet, som kvalificerer situeret viden og den enkeltes besvarelse af spørgsmålet: "Hvordan vil jeg være pædagog?" Herigennem skabes praktisk situationsanalytisk viden ${ }^{2}$.

\section{Afslutning og diskussion}

Artiklen begyndte med Linas fortælling, hvoraf det fremgår, at hun søger at finde fremme til, hvordan hun ønsker at være som pædagog. Vi har spurgt, om det er et meningsfuldt fagligt spørgsmål, og om spørgsmålet kan besvares fagligt? Vi gjorde opmærksom på, at de mest gængse vurderinger af det spørgsmål lander på én ud af to mulige positioner: Enten på en position, hvor faglighed sætter personen i baggrunden, det vil altså sige, at spørgsmålet omformuleres til "Hvordan er og handler en pædagog?", eller på en position, hvor personen skubbes i forgrunden, idet de personlige holdninger og egenskaber anses som fundamentale for, hvordan pædagogen agerer i praksis. Med afsæt i en forståelse af pædagogikkens egenart har vi tematiseret spørgsmålet om forholdet mellem fag og person ved at argumentere for, at situeret

2 Martinus Langeveld - fra 1939 til 1972 professor i pædagogik og førende fænomenologisk orienteret akademisk pædagog i Nederlandene, da den åndsvidenskabelige pædagogik var dominerende - betegnede pædagogik som en praktisk situationsanalytisk videnskab og havde i øvrigt også selv en klinisk pædagogisk praksis. 
viden - konkretisering af fagets almene værdier i situationen - er den vidensform, som er fremtrædende og påtrængende i pædagogisk praksis. Situeret viden knytter person og vidensgrundlag sammen. I artiklens anden del har vi uddybet, hvordan situeret viden ikke er en mystisk og eventyrlig størrelse, men noget, der opstår og produceres $i$ en vekselvirkning med andre vidensdimensioner og -typer, uden at den kan reduceres til disse. Pædagogen må i sidste ende selv producere sin situerede viden, der så bliver til på baggrund af en viden om og en forstålse for pædagogikkens projekt, samt et indgående kendskab til de grundlagsproblematikker og værdier, projektet omhandler og formidler. Vi har således argumenteret for, at fag og person ikke er størrelser, der udelukker hinanden, men at de har brug for hinanden: Ingen af dem har suverænitet. Dermed har vi skitseret en tredje position, som overskrider både objektivisme og subjektivisme/relativisme (Bernstein, 1983). Den er forankret i faget pædagogik, der bringer udøvelse og undersøgelse sammen som to sider af samme sag. Vi har sidst, men ikke mindst, argumenteret for, at situeret viden nok er personlig, fordi den formidles og bringes i spil af personer, men også at den må være faglig og derfor være genstand for faglig unders $\emptyset$ gelse og kritik. Det forudsætter faglige fællesskabers intersubjektivitet, hvor man sammen er optagede af og har tilgange til at unders $\emptyset$ ge og drøfte, hvordan det abstrakte pædagogiske projekt og de faglige værdier konkret balanceres og bringes i spil. Skal pædagogerne betragtes som professionsudøvere, der handler med udgangspunkt i viden, må udvikling, undersøgelse og kvalificering af den situerede viden være helt central i professionsudviklingen.

En implikation af vores udredning er, at der er brug for en tydeligere rammesætning af arbejdet med situeret viden, med fagpersonlig udvikling og med den kollektive professionsudvikling. Især må man spørge, hvordan man - såvel i uddannelsen som i styring og ledelse af feltet - kan understøtte professionsudvikling med fokus på de professionelles samlede vidensbase og vidensautoritet.

\section{REFERENCER}

Ahlström, K. G. (1988). The university and teacher training. Almqvist \& Wiksell International. Alrø, H., Billund, L. \& Herholdt-Lomholdt, S. M. (2020). Nærende relationer i professionel kontakt. I H. Alrø, L. Billund \& S. M. Herholdt-Lomholdt (Red.), Kontakt i professionelle relationer. Aalborg Universitetsforlag.

Aristoteles. (1998). Nikomachische Ethik VI (H.-G. Gadamer, Red.). Klostermann.

Bayer, M. (2017). Person. Pcedagogik, profession og forskning. Hans Reitzels Forlag.

Bayer, M. (2019). Det forventningsløse og det elastiske uddannelsesrum i praktikken - praktikken set i et uddannelsesvidenskabeligt perspektiv. In Padagoguddannelsens praktik og dens bidrag til dannelse af profesionsidentitet (s. 196-223). VIAUC \& KP. https://doi.org/10.13140/ RG.2.2.19495.70560

Bayer, M., Brinkkjær, U. \& Hui, L. J. (2012). Pædagoger, generationer og anciennitet. Pædagogers professionelle identitet og faglighed set på baggrund af deres generationsophav og anciennitet. BUPL. 
Bellmann, J. (2017). Forward to the learning sciences or back to pedagogy? I H. Saeverot \& T. C. Werler (Red.), Pedagogikkens språk. Kunnskapsformer i pedagogikkvitenskap. Gyldendal akademisk.

Bernstein, R. (1983). Beyond objectivism and relativism. Science, hermeneutics and practice. University of Pennsylvania Press.

Biesta, G. (2009). On the weakness of education. Philosophy of Education Yearbook (s. 354-362). https://dspace.stir.ac.uk/handle/1893/7445

Biesta, G. (2013). Å snakke «pedagogikk» til «education»: Internasjonalisering og problemet med konseptuell hegemoni i studiet av pedagogikk. Norsk Pedagogisk Tidsskrift, 1-14. http:// www.idunn.no/ts/npt/2013/03/aa_snakke_pedagogikk_tileducation___internasjonaliseri Biesta, G. (2014). The beautiful risk of education. Paradigm Publishers.

Biesta, G. (2015a). Teaching, teacher education, and the humanities: Reconsidering education as a Geisteswissenschaft. Educational Theory, 65(6), 665-679. https://doi.org/10.1111/edth.12141

Biesta, G. (2015b). What is education for? On good education, teacher judgement, and educational professionalism. European Journal of Education, 50(1), 75-87. https://doi.org/10.1111/ejed.12109

Biesta, G. (2018). Tijd voor pedagogiek/Time for 'pedagogiek': On the importance of 'pedagogiek' for teaching and education. Pedagogiek, 38(3), 327-348. https://doi.org/10.5117/ped2018.3.004. bies

Biesta, G. (2020). Danning og oppdragelse - om viktigheten av et skille. I T. Saevi \& G. Biesta (Red.), Pedagogikk, periferi og verdi. Fagbokforlaget.

Bille, T., Nielsen, A., Jørgensen, B. O. \& Holand, D. A. (2017). Dannelse af det pædagogiske blik i et livshistorisk perspektiv. Forskning i Pcedagogers Profession Og Uddannelse, 1(1), 55-68. https://tidsskrift.dk/FPPU/article/view/26557/23355

Gadamer, H.-G. (1999). Wahrheit und Methode. Grundzüge einer philosophischen Hermeneutik. I Gesammelte Werke 1, Hermeneutik I. J.C.B. Mohr (Paul Siebeck).

Gilje, N. (2017). Profesjonskunnskapens elementære former. I S. Mausethagen \& J.-C. Smeby (Red.), Kvalifisering til profesjonell yrkesutøvelse (s. 21-33). Universitetsforlaget.

Grimen, H. (2008). Profesjon og kunnskap. I L. I. Molander \& A. Terum (Red.), Profesjonsstudier (s. 71-86). Universitetsforlaget.

Hansen, M. A., Gravesen, D. T., Lorentsen, B. H. \& Pedersen, P. M. (2010). Pædagogprofessionens historie: Set i lyset af velfærdsstatens udvikling. Social kritik, 22(124), 68-73.

Harrits, G. S. (2019). Professionelt arbejde er en holdsport. Larerkommisionens Forskerpublikation (s. 62-68). https://www.dlf.org/media/12970686/bilag-8-laererkommissionensforskerpublikation.pdf

Harrits, G. S. \& Olesen, S. G. (2012). På vej til professionerne (1. udgave). ViaSystime.

Herbart, J. F. (1986). Die erste Vorlesung über Pädagogik: Pädagogischer Takt und das Theorie Praxis - Problem. I D. Benner (Red.), Johann Friedrich Herbart: Systematische Pädagogik, texte ausgewählt und herausgegeben von Dietrich Benner. KLett-Cotta.

Horobin, G. (1983). Professional mystery. The maintenance of charisma in general medical practice. I R. Dingwall \& P. Lewis (Red.), The sociology of the professions. Lawyers, doctors and others. Macmillan.

Jørgensen, H. H., Rothuizen, J. J. \& Togsverd, L. (2019). Pœedagogik og fortcelling. At forstå, fortolke og forny paedagogisk praksis. Samfundlitteratur.

Kant, I. (1987). Besvarelse af spørgsmålet: Hvad er oplysning? Slagmark, 9.

Larsen, L. T. (2013). Indsamle analysere systematisere. Gjallerhorn Tidsskrift for

Professionsstudier, 16, 52-61.

Løvlie, L. (2003). Det nye pedagogikkfaget. Norsk Pedagogisk Tidsskrift, 4(1,2).

Løvlie, L. (2007). Does paradox count in education? Utbildning \& Demokrati, 16(3), 9-24. 
Løvlie, L. (2015). Herbart om oppdragelse, formbarhet og takt. Nordisk Tidsskrift for Pedagogikk og Kritikk, 1(1), 1-11.

Luhmann, N. \& Schorr, E. (1979). Das Technologiedefizit der Erziehung und die Pädagogik. Zeitschrift Für Pädagogik, 25, 345-365.

Manen, M. van. (2015). Pedagogical tact. Knowing what to do when you don't know what to do. Left Coast Press.

Manuel, J. \& Hughes, J. (2006). 'It has always been my dream': Exploring pre-service teachers' motivations for choosing to teach. Teacher Development, 10(1), 5-24. https://doi. org/10.1080/13664530600587311

Mockler, N. (2011). Beyond 'what works': Understanding teacher identity as a practical and political tool. Teachers and Teaching, 17(5), 517-528. https://doi.org/10.1080/13540602.2011. 602059

Mollenhauer, K. (1983). Vergessene Zusammenhänge. Über Kultur und Erziehung. Juventa.

Oettingen, A. von. (2006). Pæedagogisk filosofi som reflekteret omgang med padagogiske antinomier. Klim.

Oettingen, A. von. (2018). Pædagogisk forskning mellem teori, empiri og praksis. Bidrag til en empirisk dannelsesforskning. I A. von Oettingen (Red.), Empirisk dannelsesforskning. Mellem teori, empiri og praksis. Hans Reitzels Forlag.

Oettingen, A. von. (2019). Pissedårlig undervisning (1. udgave). Hans Reitzel.

Oettingen, A. von \& Wiedemann (Red.). (2007). Mellem teori og praksis: Aktuelle udfordringer for pæedagogiske professioner og professionsuddannelser. Syddansk Universitetsforlag.

Olsen, B. (2015). Magt og meninger. Pædagogiske værdiprofiler blandt personalet i danske børnehaver. Tidsskrift for Nordisk Barnehageforskning, 9(5), 1-17.

Osberg, D. \& Biesta, G. (2021). Beyond curriculum: Groundwork for a non-instrumental theory of education. Educational Philosophy and Theory, 53(1), 57-70. https://doi.org/10.1080/001318 57.2020 .1750362

Polanyi, M. (1962). Personal knowledge. Towards a post-critical philosophy. The University of Chicago Press, Routledge \& Kegan Paul.

Rothuizen, J. J. (2001). Pæedagogisk arbejde på fremmed grund. På vej mod en ny forståelse af pæedagogisk faglighed og praksis. Gyldendal Uddannelse.

Rothuizen, J. J. (2015). På sporet af pædagogisk faglighed. Pædagoguddannelsens deltagelse i det pædagogiske projekt. DPU. https://viauc.academia.edu/janjaaprothuizen

Rothuizen, J. J. (2019). Om og for praksis. Pædagogik som handlingsvidenskab. Studier i Pcedagogisk Filosofi, 8(2). https://doi.org/10.7146/spf.v8i2.110456

Rothuizen, J. J. (2021). Mellem viden og handling. I H. H. Hjermitslev, B. M. Rasmussen \& L. Togsverd (Red.), God og dårlig padagoguddannelse. 18 skarpe tekster om landets største videregående uddannelse (s. 71-82). Forlaget DPP.

Rothuizen, J. J. \& Togsverd, L. (2020). Det pæedagogiske projekt. Om at udøve, undersøge og udvikle poedagogisk praksis. Akademisk Forlag.

Rothuizen, J. J., Togsverd, L., Bayer, M., Højberg, B. \& Falkenberg, H. (2019). Pcedagoguddannelsens praktik og dens bidrag til dannelse af professionsidentitet. Rapporteringer fra et forskningsprojekt. VIAUC\&KP. https://doi.org/10.13140/RG.2.2.19495.70560

Rothuizen, J. J., Togsverd, L., Bøje, J. D., Hansen, S. J., Hjort, K. \& Sørensen, M. M. (2013). Hvordan uddannes pædagoger. Perspektiver fra et forskningsprojekt. https://bit.ly/academiahvordan

Saeverot, H. (2017). Pedagogikk er en handlingsvitenskap. I H. Saeverot \& T. C. Werler (Red.), Pedagogikkens språk. Kunnskapsformer i pedagogikkvitenskap. Gyldendal akademisk.

Schön, D. A. (2001). Den reflekterende praktiker: hvordan professionelle tæenker når de arbejder (1. udg.). Klim. 
Sørensen, M. \& Rothuizen, J. J. (2013). Survey-undersøgelsen på pædagoguddannelsen Peter Sabroe. I J. J. Rothuizen \& L. Togsverd (Red.), Hvordan uddannes paedagoger? Perspektiver fra et forskningsprojekt. VIAUC, Videncenter for socialpædagogik og socialt arbejde.

Steinsholt, K. \& Løvlie, L. (Red.). (2005). Pedagogikkens mange ansikter: pedagogikkens idéhistorie fra antikken til det postmoderne. Universitetsforlaget.

Togsverd, L., \& Rothuizen, J. J. (2020). Hvordan danner pcedagogstuderende professionsidentitet $i$ pæedagoguddannelsen? DS. https://doi.org/10.13140/RG.2.2.34595.20008

Watt, H.M.G., Richardson, P.W., Klusmann, U., Kunter, M., Beyer, B., Trautwein, U. \& Baumert, J. (2012). Motivations for choosing teaching as a career: An international comparison using the FIT-Choice scale. Teaching and Teacher Education, 28(6), 791-805. https://doi.org/10.1016/ j.tate.2012.03.003

Watt, H. \& Richardson, P. (2007). Motivational factors influencing teaching as a career choice: Development and validation of the FIT-choice scale. Journal of Experimental Education - J EXP EDUC, 75, 167-202. https://doi.org/10.3200/JEXE.75.3.167-202 